\title{
Suzi Mikulić
}

Hrvatske Telekomunikacije d.d., Kneza Branimira b.b., Mostar suzi.mikulic@gmail.com

\section{UTJECAJ RAZINE OBJAVA EMITENATA NA TRŽIŠTU KAPITALA U FEDERECIJI BOSNE I HERCEGOVINE NA UKUPNU RENTABILNOST DIONICE I PRINOS DIONICE}

Primljeno: 24. rujna 2020.

Prihvaćeno: 16. listopada 2020.

https://doi.org/10.46458/27121097.2020.26.146

Pregledni rad

\section{Sažetak}

Informacije predstavljaju jedan od osnovnih resursa poslovanja i bez njih nije moguće donositi kvalitetne i pravodobne poslovne odluke. Razvojem financijskih tržišta i sve većim brojem zainteresiranih strana za informacijama zahtjevi za objavama se kontinuirano povećavaju. Način na koji emitenti komuniciraju sa potencijalnim investitorima $i$ svim ostalim zainteresiranim stranama su javno dostupne objave bilo da se radi o obveznim ili dobrovoljnim objavama. U ovom radu istražuju se objave emitenata na tržištu kapitala u Federaciji BiH, svrstanih u Segment 1 (ST1) Sarajevske burze (SASE), u razdoblju od 2013. do 2018. godine, te da li razina objava informacija o poslovanju utječe na ukupnu rentabilnost dionice i prinos dionice emitenata. Provedenim istraživanjem utvrđeno je da emitenti svrstani u STI ispunjavaju djelomično zakonski propisane obaveze u objavljivanju informacija, odnosno objavljuju samo glavni set financijskih izvještaja dok izvještaj vanjskog revizora koji je mehanizam kontrole financijskih izvještaja nije objavljen kod značajnog broja emitenata iz uzorka. Opseg objavljivanja dobrovoljnih informacija nije na zadovoljavajućoj razini što može biti posljedica još uvijek relativno nerazvijenog tržišta kapitala u F BiH u odnosu na razvijenije zemlje te činjenice da Bosna i Hercegovina nije članica Europske unije i još nije uskladila zakonsku regulativu sa regulatornim okvirom EU koja se tiče pravila korporativnog izvještavanja. Izvršenom regresijskom analizom nije potvrđen utjecaj razine objava emitenata o poslovanju na ukupnu rentabilnost dionice i prinos dionice emitenata.

Ključne riječi: objave informacija, financijski izvještaji, ukupna rentabilnost dionice, prinos dionice;

JEL: G30, M40, M41 


\section{UVOD}

Potreba za dobivanjem pouzdanih financijskih informacija u današnjem globaliziranom svijetu je od izuzetne važnosti pri donošenju poslovnih odluka. Financijski izvještaji su jedan od glavnih izvora financijskih informacija a nastaju kao proizvod financijskog računovodstva. Oni trebaju dati informacije o financijskom položaju poslovnog subjekta na određeni dan i informacije o rezultatima poslovanja u određenom razdoblju.

Informacija iz financijskih izvještaja je korisna ako ima utjecaj na odluke korisnika financijskih izvještaja a značajna je ako njeno izostavljanje može promijeniti odluku ulagača. Kvalitativna obilježja koja bi trebala imati svaka financijska informacija su: razumljivost, važnost, pouzdanost i usporedivost. Razvoj internet tehnologije je omogućio i olakšao poslovnim subjektima komunikaciju sa svojim korisnicima. Trenutna praksa u svijetu je da subjekti listani na burzama sve informacije o poslovanju javno objavljuju na internet stranicama. Na taj način udovoljavaju različitim tržišnim i društvenim očekivanjima ali i zakonskim zahtjevima u pogledu objavljivanja informacija i izvještaja. Korporativno izvještavanje je način na koji poslovni subjekti komuniciraju sa ulagačima ali i ostalim zainteresiranih stranama i u razvijenim gospodarstvima i financijskim tržištima je regulirano kao obaveza.

Kvalitetan sustav korporativnog izvještavanja treba doprinijeti povećanju transparentnosti i jačanju povjerenja svih zainteresiranih korisnika informacija u financijsko izvještavanje te prezentirane informacije u objavama.

Cilj ovog istraživanja je utvrditi opseg objavljivanja financijskih informacija od strane emitenata odnosno poslovnih subjekata svrstanih u Segment 1 Sarajevske burze, da li ispunjavaju zakonske zahtjeve za objavljivanjima te da li veća razina objava informacija o poslovanju, utječe na ukupnu rentabilnost dionice i prinos dionice emitenata. Ukupna rentabilnost dionice se ubraja u najvažnije pokazatelje investiranja dok je prinos dionice ključan indikator $u$ analizi potencijalnih investitora za ulaganje $\mathrm{u}$ određene dionice.

Postizanje navedenih ciljeva istraživanja zahtijevati će pronalazak odgovora na sljedeća pitanja:

- Da li emitenti na tržištu kapitala svrstani u Segment 1 Sarajevske burze objavljuju zakonski obavezne informacije i izvještaje i u kojem obimu?

- Da li emitenti na tržištu kapitala svrstani u Segment 1 Sarajevske burze objavljuju dobrovoljno dodatne informacije koje mogu biti od značaja za zainteresirane korisnike informacija? 
- Da li oni emitenti koji ispunjavaju zakonske obaveze u objavljivanju informacija imaju i bolje pokazatelje, ukupnu rentabilnost dionice i prinos po dionici emitenta, odnosno da li razina objava informacija o poslovanju utječe na ukupnu rentabilnost dionice i prinos dionica emitenata?

Nastavno na prethodno navedeno i pretpostavke da bi objave informacija o poslovanju kroz usvojene pozitivne prakse korporativnog izvještavanja te poštivanje zakonom definiranih obaveza u objavama trebale doprinijeti transparentnosti i većem povjerenju investitora, očekuje se pozitivna povezanost razine objava informacija o poslovanju i ukupne rentabilnosti dionice te prinosa dionice emitenata.

\section{ZNAČAJ KVALITETE FINANCIJSKIH IZVJEŠTAJA KAO IZVORA FINANCIJSKIH INFORMACIJA}

\subsection{Financijski izvještaji kao izvor financijskih informacija}

Financijski izvještaji predstavljaju glavni izvor financijskih informacija o poslovanju određenog poslovnog subjekta. Cilj im je pružanje informacija o financijskom stanju, uspješnosti poslovanja i novčanim tokovima poslovnog subjekta koji utječu na ekonomske odluke investitora (Brkanić, 2007.). Financijski izvještaju pružaju i ostale informacije koje su od koristi širem krugu korisnika. Za financijsko izvještavanje u Federaciji Bosne i Hercegovine relevantni su Zakon o računovodstvu i reviziji $\mathrm{BiH}$, Zakon o računovodstvu i reviziji $\mathrm{F}$ BiH te Međunarodni računovodstveni standardi (MRS-evi) i Međunarodni standardi financijskog izvještavanja (MSFI-evi). Potpuni set financijskih izvještaja čine: Izvještaj o financijskom položaju na kraju razdoblja - Bilanca stanja, Izvještaj o sveobuhvatnoj dobiti razdoblja - Bilanca uspjeha, Izvještaj o promjenama kapitala tijekom razdoblja, Izvještaj o novčanim tokovima tijekom razdoblja, Bilješke uz financijske izvještaje. ${ }^{1}$ Poslovni subjekti sastavljaju financijske izvještaje, osim izvještaja o novčanim tokovima, prema načelu nastanka događaja, odnosno prema obračunskoj osnovi računovodstva. Poslovne transakcije i događaji se priznaju u trenutku njihovog nastanka a ne po primitku novca ili novčanog ekvivalenta.

Financijske izvještaje kao glavni izvor financijskih informacija treba sastavljati i prezentirati imajući u vidu njihove informacijske potrebe. To se prvenstveno odnosi na korisnike koji svoje poslovne odluke temelje samo na informacijama iz financijskih izvještaja. Korisnici financijskih izvještaja mogu biti interni i eksterni. Najznačajniji interni korisnici su menadžment i zaposlenici poslovnog

MRS 1 - Prezentiranje financijskih izvještaja 
subjekta, dok su eksterni korisnici u prvom redu investitori te kupci, zajmodavci, dobavljači i ostali vjerovnici, država i njezine agencije te javnost. Navedeni korisnici financijskih izvještaja nastoje na temelju prezentiranih informacija donijeti kvalitetne poslovne odluke. Odluke mogu biti vezane za kupnju, prodaju ili držanje dionica te za utvrđivanje financijske pozicije poslovnog subjekta i sposobnost podmirivanja obaveza.

Informacije predstavljaju jedan od osnovnih resursa poslovanja, i bez njih nije moguće donositi kvalitetne i pravodobne poslovne odluke. Kako bi se donosilo kvalitetne poslovne odluke moraju biti poznate informacije o okruženju ali i informacije o poslovanju samog poslovnog subjekta. Informacije moraju biti točne, potpune, kvalitetne i dostupne u pravo vrijeme kako bi imale pozitivan poslovni učinak. Danas se menadžeri moraju suočavati sa sve većim brojem internih i eksternih informacija pomoću kojih donose brže i bolje odluke. Pristup potpunijim, selektivnijim i ažurnijim informacijama postaje nužnost, te informacije poprimaju stratešku važnost.

Imperativ kvalitetnog odlučivanja je kako smanjiti rizik i neizvjesnost u procesu poslovnog odlučivanja a to se postiže prikupljanjem kvalitetne informacijske podloge. Informacije potrebne za donošenje odluka mogu se pribaviti iz različitih izvora. Nefinancijske informacije su jednako važne kao i financijske i značajan segment informacija za potrebe poslovnog odlučivanja sadržan je u obliku financijskih izvještaja. Kada bi svi sudionici na tržištu raspolagali potpunim i istinitim informacijama moglo bi se reći da su na tržištu prisutni idealni uvjeti koji bi omogućili minimalne transakcijske troškove. Međutim, idealni uvjeti rijetko gdje postoje pa tako i na tržištu. Puno je češća situacija da na tržištu jedan od sudionika raspolaže sa potpunijim i objektivnijim informacijama od drugih sudionika. Situacija na tržištu u kojoj pojedini sudionici raspolažu sa više informacija ili objektivnijim i istinitijim informacijama naziva se asimetrija informacija (Mishkin i Eakins, 2005.).

Kod asimetrije informacija treba razlikovati javno dostupne od povlaštenih informacija. Javno dostupne informacije su informacije koju su poznate, odnosno dostupne svim korisnicima bez obzira da li se radi o investitorima, kreditorima ili drugim zainteresiranim stranama. Javne informacije se prezentiraju u korporativnim izvještajima, izjavama za medije ili intervjuima a na korisnicima je dođu do njih. Prema Zakonu o tržištu vrijednosnih papira u Federaciji $\mathrm{BiH}^{2}$ povlaštena informacija u smislu odredaba ovog zakona „, predstavlja privilegiranu, povjerljivu, odnosno svaku informaciju ili događaj koja osobi koja njom raspolaže daje prednost u odnosu na druge sudionike u prometu vrijednosnih papira i koja može imati utjecaj na emitenta vrijednosnih papira ili na tržište na kojem se prometuje

2 Zakon o tržištu vrijednosnih papira F BiH, članak 220, Službene novine F BiH broj 58/08 
vrijednosnim papirima i cijenu emitiranih vrijednosnih papira, a koja još nije javno objavljena". Zakonskim odredbama zabranjeno je korištenje povlaštenih informacija u svrhu manipulacije cijenama vrijednosnih papira. Postoje dva pojavna oblika asimetrije informacija i to su problem nepovoljnog izbora i problem moralnog hazarda. Informacijska asimetrija se ne može u potpunosti eliminirati ali se njeni učinci mogu smanjiti kvalitetnim i transparentnim korporativnim izvještavanjem.

O kvalitetnom financijskom izvještavanju se može govoriti ako ono osigurava objektivno i potpuno predstavljanje ekonomskih performansi, financijske pozicije i rizika kojima je gospodarsko društvo izloženo, te relevantne informacije za prognozu financijske situacije i uspješnosti poslovanja u narednom periodu. Kvalitetan sustav financijskog izvještavanja će stvoriti povoljno okruženje za povećanje povjerenja investitora, njihovu investicijsku aktivnost što će pozitivno utjecati na gospodarsku aktivnost u cjelini. Pored zadovoljenja navedenih kvalitativnih karakteristika, objektivnosti, potpunosti i relevantnosti, neophodna je i implementacija standarda koji se odnose na financijsko izvještavanje kao i etičko ponašanje kreatora financijskih izvještaja te revizora koji ocjenjuju da li prezentirani financijski izvještaji odražavaju fer i objektivno iskazana stanja i rezultate poslovanja.

\subsection{Dobrovoljno izvještavanje kao izvor dodatnih financijskih i nefinancijskih informacija}

Dobrovoljno izvještavanje podrazumijeva objavu i pružanje dodatnih informacija od strane uprave tvrtke zainteresiranim korisnicima izvještaja koje nije regulirano zakonskim i drugim relevantnim propisima kao što su međunarodni računovodstveni standardi i međunarodni standardi financijskog izvještavanja. Svrha mu je povećanje transparentnosti, smanjenje rizika ulaganja te troškova financiranja. Za dobrovoljno izvještavanje se odlučuju brojne korporacije u razvijenim gospodarstvima jer smatraju da su im koristi veće od troškova. Koristi koje mogu proizaći iz dobrovoljnog izvještavanja su smanjenje informacijske asimetrije, jačanje povjerenja ulagača te smanjenje troškova financiranja. Dobrovoljno izvještavanje se mjeri količinom financijskih i nefinancijskih informacija koje korporacije daju u javnost. Primjeri takvih informacija su definiranje poslovnih ciljeva i strategije, analiza konkurencije, analiza ključnih proizvoda i tržišta na kojima kompanija posluje, menadžerske prognoze i analize poslovanja i financijskih rezultata, analiza rizika, financijski pokazatelji, podaci o kretanju cijena dionica, opis kvalifikacija i stručnosti zaposlenika. Dobrovoljno izvještavanje proizlazi iz prakse dobrog korporativnog upravljanja a regulativa koja se do sada primjenjivala u Europskoj uniji u pogledu korporativnog izvještavanja 
nije urodila željenim rezultatima prvenstveno jer je dozvolila puno različitih alternativa u svrhu poštivanja pravnih i poreznih razlika država članica Europske unije. Europski parlament je 15.04.2014. godine usvojio prijedlog Europske komisije o direktivi za nefinancijsko izvještavanje (Direktiva 2014/95/EU) koja je u primjeni od početka 2017. godine. Cilj direktive je unaprijediti i poboljšati transparentnost nefinancijskog izvještavanje unutar Europske unije a obuhvaća one poslovne subjekte koji ispunjavaju sljedeće kriterije: ukupna aktiva 20 mil. EUR ili prihod 40 mil. EUR - veliki poslovni subjekti, više od 500 zaposlenika te poslovni subjekti od javnog interesa - kotiraju na EU burzama, banke ili osiguranja, ili je subjekt od javnog interesa prema nacionalnom zakonu zemlje članice.

Subjekti koji ispunjavaju navedene kriterije trebaju objaviti u obliku nefinancijskog izvješća nefinancijske informacije vezane za razumijevanje razvoja, financijskog položaja i financijske uspješnosti poslovnog subjekta, učinke njegovih aktivnosti koje se odnose na okolišna, socijalna i kadrovska pitanja, poštivanje ljudskih prava, borbu protiv korupcije i pitanja vezana uz podmićivanje. Nefinancijsko izvješće treba sadržavati i kratak opis poslovnog modela poslovnog subjekta, opis politika poslovnog subjekta u vezi s tim pitanjima, uključujući postupke temeljite analize koji se provode, rezultate tih mjera, osnovne rizike povezane s tim pitanjima koji se odnose na poslovanje subjekta, uključujući, kad je to relevantno i razmjerno, njegove poslovne odnose, proizvode ili usluge koji mogu prouzročiti negativne učinke na tim područjima, te način na koji poslovni subjekt upravlja tim rizicima te nefinancijske ključne pokazatelje uspješnosti važne za određeno poslovanje (Gulin at al.2016).

\subsection{Institucionalni okvir izvještavanja emitenata na tržištu kapitala u Federaciji BiH}

Pored općeg regulatornog okvira za financijsko izvještavanje, za emitente na tržištu kapitala Federacije BiH mjerodavan je i Pravilnik o objavljivanju informacija i izvještavanju na tržištu kapitala. Njime se pobliže definira sadržaj, način i rokovi dostavljanja, objavljivanja izvještaja i informacija emitenata, ovlaštenih učesnika na tržištu vrijednosnih papira, burze, registra vrijednosnih papira u Federaciji $\mathrm{BiH}$ i samo regulirajuće organizacije kao i sadržaj obavještenja o transakcijama na osnovu povlaštenih informacija. Navedeni Pravilnik definira sljedeće obaveze emitenata u izvještavanju i objavljivanju informacija: objavljivanje polugodišnjeg i godišnjeg izvještaja o poslovanju i izvještaja vanjskog revizora na svojoj web stranici i dostavljanje burzi radi objavljivanja na web stranici burze te objavljivanje izvještaja o događajima koji bitno utječu na financijsko poslovanje emitenta. 
Godišnji izvještaj o poslovanju emitenata bi trebao sadržavati i prikaz primijenjenih pravila korporativnog upravljanja. Navedeni izvještaji se dostavljaju u sljedećim rokovima: godišnji izvještaj o poslovanju do 30.travnja tekuće godine za prethodnu godinu, polugodišnji izvještaj najkasnije do 31.kolovoza tekuće godine, cjelovit izvještaj vanjskog revizora o obavljenoj reviziji godišnjeg izvještaja o poslovanju emitenta, do dana održavanja skupštine emitenta na kojoj će izvještaj biti razmatran a najkasnije šest mjeseci od završetka poslovne godine i izvještaji o događajima koji bitno utječu na financijsko poslovanje, u roku od 8 dana od dana događaja. U slučaju da skupština emitenta ne usvoji godišnji izvještaj o poslovanju koji uključuje i izvještaj vanjskog revizora emitent je dužan odluku skupštine o neusvajanju godišnjeg izvještaja o poslovanju objaviti u roku od 8 dana od dana donošenja odluke. Izmjenama Pravilnika o objavljivanju informacija i izvještavanju na tržištu vrijednosnih papira (Službene novine F BiH, br. 65/19) skraćeni su rokovi za dostavu izvještaja i to Godišnji izvještaj o poslovanju do zadnjeg dana mjeseca veljače tekuće godine za prethodnu a polugodišnji izvještaj o poslovanju do 31.srpnja tekuće godine. Za istraživanje razine objava i urednosti u pravovremenoj dostavi izvještaja za objavu u ovom istraživanju kao relevantan uzet je Pravilnik o objavljivanju informacija i izvještavanju na tržištu vrijednosnih papira u Federaciji BiH (Službene novine F BiH, br. 35/13) budući je bio na snazi za vremensko razdoblje ovog istraživanja.

\section{PREGLED PRETHODNIH ISTRAŽIVANJA}

Istraživanja na temu objavljivanja informacija o poslovanju provođena su na više različitih načina. Dio autora je istraživao u kojoj mjeri se objavljuju informacije, dio autora čimbenike koji utječu na razinu objava dok je dio istraživao povezanost objava i određenih pokazatelja poslovanja.

Botosan (1997.) je u svom istraživanju proučavao odnos dobrovoljnog objavljivanja i troškova vlasničkog kapitala, koristeći tržišnu $\beta$ vrijednost za procjenu troškova vlasničkog kapitala. Zaključci njegovog istraživanja upućuju da kod poslovnih subjekata koji privlače manje pažnje analitičara postoji negativna povezanost između objava i troškova kapitala a kod poslovnih subjekata kojima se više bave analitičari nije utvrđena značajna veza između razine objava i troškova kapitala.

Madhani (2007.) u svojoj studiji tvrdi da prakse dobrovoljnog objavljivanja povećavaju svijest i povjerenje investitora, smanjujući nesigurnost prinosa dobavljačima kapitala. 
Hussainey i Walker (2009.) istražuju povezanost zajedničkih učinaka subjekata koji isplaćuju dividende i dobrovoljno objavljuju podatke sa trenutnim prinosom na dionice i budućim zaradama te da li se razlikuju među poslovnim subjektima sa niskim i visokim rastom. Zaključci istraživanja upućuju da se predviđanje zarade po dionici poboljšava sa razinom objavljivanja narativnog godišnjeg izvještaja te da subjekti koji isplaćuju dividende pokazuju veću razinu očekivane zarade po dionici od subjekata koja ne isplaćuju dividendu. Navedeni zaključci su se pokazali statistički značajni za subjekte sa visokim rastom iako nisu savršeno aditivni, dok su beznačajni za subjekte s niskim rastom.

Zareian (2012.) u istraživanju povezanosti dobrovoljnih objava emitenata na tržištu kapitala u Iranu sa tržišnim povratima na dionice nije utvrdio značajnu povezanost između istih. S druge pak strane, Mwangi i Mwiti (2015.) u istraživanju povezanosti dobrovoljnih objava sa tržišnim povratima na dionice na uzorku listanih subjekata na NSE ( Nairobi Securities Exchange) zaključuju da postoji pozitivna povezanost između objava informacija o poslovanju sa tržišnim povratom na dionice promatranog kroz odnos dividende po dionici i tržišne cijene dionice.

Gulin at al. (2016.) istražuju razinu usklađenosti korporativnog izvještavanja poslovnih subjekata koji kotiraju na burzama u Hrvatskoj i u Federaciji Bosni i Hercegovini sa regulatornim zahtjevima za korporativnim izvještavanjem u Europskoj uniji. Zaključak istraživanja upućuje da je regulatorni okvir korporativnog izvještavanja u Republici Hrvatskoj u potpunosti usklađen sa regulatornim okvirom za korporativno izvještavanje Europske unije što nije slučaj u Federaciji $\mathrm{BiH}$ te da je u Hrvatskoj prisutna značajno veća razina transparentnosti u objavama u odnosu na Federaciju BiH.

Sahore i Verma (2017.) istražuju da li objavljivanja podatka o poslovanju na dobrovoljnoj osnovi imaju utjecaja na tržišnu cijenu dionica. Korporativna objavljivanja su promatrali kroz tri kategorije, dobrovoljne objave financijskih informacija, dobrovoljne objave nefinancijskih informacija i ukupne dobrovoljne objave. Kao glavne zaključke istraživanja navode da cijena dionica reagira na objavljivanja i financijska i ne financijska te da ne ovisi primarno o razini objava već o vrsti informacije koja se objavljuje. Autori također naglašavaju ulogu objavljivanja informacija u smanjenju informacijske asimetrije ali i važnost procjene mogućih ekonomskih posljedica dobrovoljnog otkrivanja podataka. 


\section{METODOLOGIJA I REZULTATI ISTRAŽIVANJA}

\subsection{Metodologija istraživanja i uzorak}

Istraživanje se provodilo u svibnju 2020. godine a analizirali su se podaci poslovnih subjekata (emitenata) na tržištu kapitala u Federaciji BiH, odnosno na Sarajevskoj burzi vrijednosnih papira ( SASE), svrstanih u Segment 1 Slobodnog tržišta ${ }^{3} u$ šestogodišnjem razdoblju od 2013. do 2018. godine. U uzorku su zastupljene sve glavne grane gospodarstva u Federaciji Bosne i Hercegovine. Najviše poslovnih subjekata iz uzorka je iz proizvodnog sektora bilo da se radi o proizvodnji industrijskih ili potrošačkih dobara.

Grafikon 1. Struktura djelatnosti emitenata uključenih u uzorak

\section{Struktura djelatnosti}

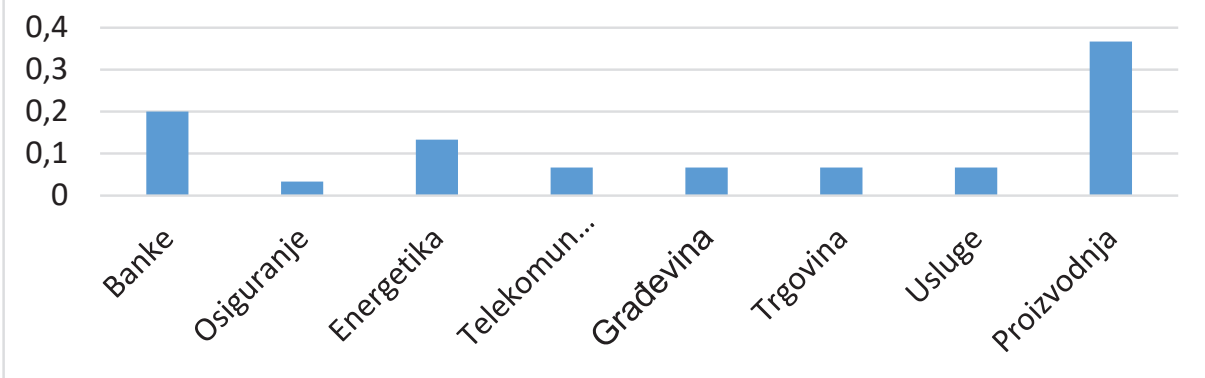

Izvor: Obrada autora

Tijekom promatranog razdoblja 5 emitenata je izuzeto iz istraživanja ( 3 emitenta su otišla u stečaj, 2 emitenta su prodana i više ne kotiraju) dok je u analizu uključeno 7 novih emitenata tako da je ukupan broj analiziranih emitenata 32. Tijekom promatranog razdoblja pojedini emitenti su presegmentirani u niže segmente ( ST 2 i ST 3) ali su za potrebe istraživanja analizirani i njihovi podaci jer su u određenom razdoblju bili sudionici Segmenta 1. Broj opservacijskih jedinica u uzorku kod testiranja utjecaja razine objava na ukupnu rentabilnost dionice i prinos dionice iznosi 184 jedinice. Jeden emitent je isključen iz analize zbog visokih

3 Na ST1 su uvrštene dionice 30 emitenata koje spadaju u red najlikvidnijih vrijednosnih papira na Slobodnom tržištu, koji istovremeno imaju free-float faktor od miminalno $25 \%$ ili alternativno vrijednost tržišne kapitalizacije raspoložive investitorima od minimalno 2 miliona KM, na dan vršenja revizije, te koji redovno izvršavaju svoje obaveze izvještavanja. Revizija simbola na ST1 se vrši na polugodišnjem nivou. Statički limiti iznose $+/-20$ \% u odnosu na zadnji službeni jedinstveni kurs. 
vrijednosti ( izdvojenica) dok za jednog emitenta nisu bili dostupni podaci za 2013. i 2014. godinu jer nije bio emitent SASE u tom razdoblju.

Tablica 1. Definiranje uzorka za potrebe empirijskog dijela istraživanja

\begin{tabular}{|l|c|}
\hline $\begin{array}{l}\text { Ukupan broj jedinica (opservacija) uključenih u uzorak u raz- } \\
\text { doblju od 2013.-2018. godine (32x6 godina) }\end{array}$ & 192 \\
\hline $\begin{array}{l}\text { Emitenti za koje se nisu mogli osigurati podaci za cijelo razdoblje } \\
\text { istraživanja ( 1x2 godine) }\end{array}$ & 2 \\
\hline $\begin{array}{l}\text { Emitenti isključeni iz empirijske analize zbog visokih vrijednosti } \\
\text { promatranih pokazatelja - izdvojenice (1x6 godina) }\end{array}$ & 6 \\
\hline $\begin{array}{l}\text { Ukupan broj jedinica (opservacija) uključenih u uzorak u raz- } \\
\text { doblju od 2013.-2018. godine }\end{array}$ & 184 \\
\hline
\end{tabular}

Izvor: autor

Za potrebe istraživanja korišteni su javno dostupni podaci sa internet stranice Sarajevske burze - SASE (www.sase.ba) i emitenata koja ulaze u uzorak.

Podaci su prikupljani u MS Excel bazu podataka a za statističku analizu se koristio EViews statistički program. Podaci su obrađivani metodama analize sadržaja, deskriptivne statistike i regresijskim analizama.

\subsection{Rezultati provedenog empirijskog istraživanja}

Za ukupno 32 emitenta provedena je analiza njihovih financijskih rezultata ostvarenih u razdoblju istraživanja. Za jednog emitenta nisu bili dostupni podaci za 2013. i 2014. godinu jer u tom razdoblju nije bio emitent SASE dok za ostale godine jesu.

Grafikgn 2. Financijski rezultati emitenata ostvareni u razdoblju od 2013. do 2018. godine

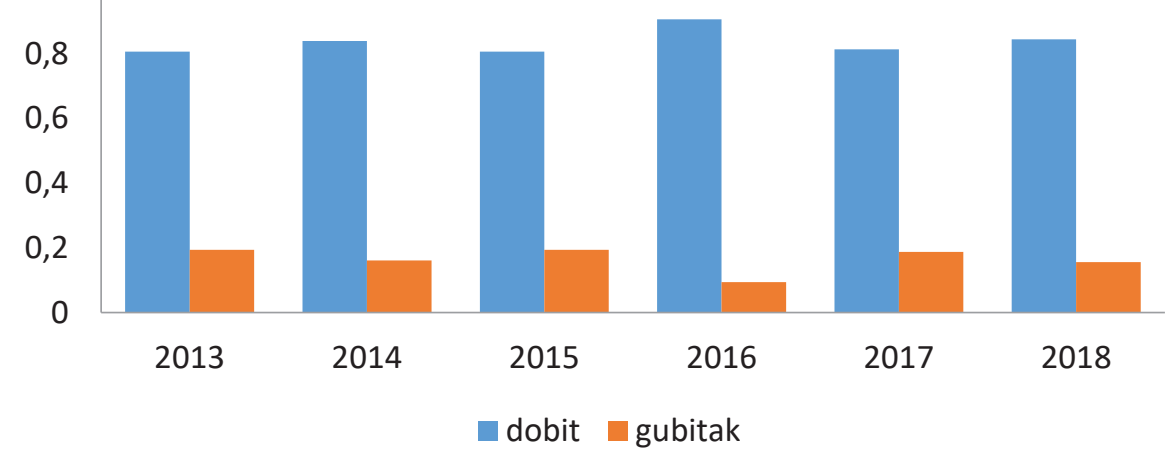

Izvor : Obrada autora 
Provedenom analizom sadržaja javno dostupnih financijskih izvještaja emitenata u promatranom razdoblju više od $80 \%$ emitenata ostvarilo je dobit i imalo zaradu po dionici. Najveći postotak emitenata koji su ostvarili dobit je u 2016. godini (90,6\%), a najmanje u 2013. i 2015. godini.

Prvo istraživačko pitanje se odnosilo na pronalazak odgovora da li emitenti na tržištu kapitala Federacije BiH svrstani u Segment 1 Sarajevske burze objavljuju zakonski obavezne informacije i izvještaje i u kojem obimu? Odgovor na navedeno pitanje prezentiran je putem deskriptivne statistike u tablici niže.

Tablica 2. Deskriptivna statistika objavljivanja informacija iz poslovanja

\begin{tabular}{|c|c|c|c|c|c|c|c|c|c|c|c|}
\hline & God. & PG & M & GOD & $\mathrm{M}$ & $\begin{array}{c}\text { Objave } \\
\text { doga- } \\
\text { đaja }\end{array}$ & M & $\begin{array}{c}\text { Revi- } \\
\text { zorski } \\
\text { izvještaj }\end{array}$ & $\mathrm{M}$ & $\begin{array}{l}\text { Cijeli set } \\
\text { izvještaja }\end{array}$ & M \\
\hline \multirow{6}{*}{ Objavili } & 2013 & 28 & \multirow{6}{*}{31} & 31 & \multirow{6}{*}{32} & 30 & \multirow{6}{*}{31} & 20 & \multirow{6}{*}{22} & 20 & \multirow{6}{*}{22} \\
\hline & 2014 & 31 & & 31 & & 30 & & 19 & & 19 & \\
\hline & 2015 & 31 & & 32 & & 31 & & 29 & & 27 & \\
\hline & 2016 & 31 & & 32 & & 30 & & 21 & & 21 & \\
\hline & 2017 & 32 & & 32 & & 31 & & 23 & & 23 & \\
\hline & 2018 & 32 & & 32 & & 32 & & 22 & & 21 & \\
\hline \multirow{6}{*}{$\begin{array}{c}\text { Nisu } \\
\text { objavili }\end{array}$} & 2013 & 3 & & 0 & \multirow{6}{*}{0} & 1 & \multirow{6}{*}{1} & 11 & \multirow{6}{*}{9} & 11 & \multirow{6}{*}{10} \\
\hline & 2014 & 0 & & 0 & & 1 & & 12 & & 12 & \\
\hline & 2015 & 1 & & 0 & & 1 & & 3 & & 5 & \\
\hline & 2016 & 1 & 1 & 0 & & 2 & & 11 & & 11 & \\
\hline & 2017 & 0 & & 0 & & 1 & & 9 & & 9 & \\
\hline & 2018 & 0 & & 0 & & 0 & & 10 & & 11 & \\
\hline \multirow{6}{*}{$\begin{array}{c}\text { Objavili do } \\
\text { zakonskog } \\
\text { roka }\end{array}$} & 2013 & 20 & & 21 & \multirow{6}{*}{21} & 30 & \multirow{6}{*}{29} & 13 & \multirow{6}{*}{14} & 7 & \multirow{6}{*}{9} \\
\hline & 2014 & 20 & & 21 & & 30 & & 11 & & 10 & \\
\hline & 2015 & 20 & & 18 & & 27 & & 12 & & 6 & \\
\hline & 2016 & 23 & 21 & 22 & & 29 & & 16 & & 9 & \\
\hline & 2017 & 18 & & 22 & & 29 & & 15 & & 8 & \\
\hline & 2018 & 24 & & 24 & & 30 & & 15 & & 11 & \\
\hline \multirow{6}{*}{$\begin{array}{c}\text { Objavili } \\
\text { iza } \\
\text { zakonskog } \\
\text { roka }\end{array}$} & 2013 & 8 & \multirow{6}{*}{10} & 10 & \multirow{6}{*}{10} & 0 & \multirow{6}{*}{2} & 7 & \multirow{6}{*}{9} & 13 & \multirow{6}{*}{13} \\
\hline & 2014 & 11 & & 10 & & 0 & & 8 & & 9 & \\
\hline & 2015 & 11 & & 14 & & 4 & & 17 & & 21 & \\
\hline & 2016 & 8 & & 10 & & 1 & & 5 & & 12 & \\
\hline & 2017 & 14 & & 10 & & 2 & & 8 & & 15 & \\
\hline & 2018 & 8 & & 8 & & 2 & & 7 & & 10 & \\
\hline
\end{tabular}

God- Godina, PG- Polugodišnji izvještaj o poslovanju, GOD - Godišnji izvještaj o poslovanju, M-Mod

Izvor: Obrada autora 
U prosjeku za sve promatrane godine 22 emitenta objavi zakonom zahtijevane informacije od čega 9 emitenata u zakonom predviđenomu roku a 13 iza zakonskog roka. Od četiri zahtijevana izvještaja emitenti objavljuju u najvećem broju tri izvještaja, godišnji $(M=32)$, polugodišnji $(M=31)$ i objave o događajima koji bitno utječu na poslovanje $(M=31)$ dok je izvještaj vanjskog revizora, izvještaj koji najčešće nedostaje $(\mathrm{M}=22)$.

Drugo istraživačko pitanje odnosilo se na pronalazak odgovora da li emitenti na tržištu kapitala svrstani u Segment 1 Sarajevske burze objavljuju dobrovoljno dodatne informacije koje mogu biti od značaja za zainteresirane korisnike informacija? Analizom sadržaja polugodišnjeg i godišnjeg izvještaja utvrđeno je da se u dijelu obrasca koji se odnosi na zabilješke i komentare uprave neophodne za bolje razumijevanje prezentiranih podataka u financijskim izvještajima ne objavljuje ništa, odnosno ne daju se informacije koje bi mogle biti od koristi zainteresiranim korisnicima za bolje razumijevanje podataka prezentiranih u financijskim izvještajima. Što se tiče objava događaja koji bitno utječu na poslovanje većina emitenata ih objavljuje a najčešće se odnose na informaciju javnosti o sazivanju skupštine društva, točkama dnevnog reda te odlukama donesenim na istoj.

Treće istraživačko pitanje se odnosilo na pronalazak odgovora da li oni emitenti koji ispunjavaju zakonske obaveze u objavljivanju informacija imaju i bolje pokazatelje, ukupnu rentabilnost dionice i prinos dionice emitenta, odnosno da li razina objava o poslovanju emitenta utječe na pokazatelje ukupnu rentabilnost dionice i prinos dionice emitenata? Odgovor na navedeno pitanje prezentirati će se putem regresijske analize, pri čemu su analizirana dva modela.

Zavisne varijable u modelima su izabrani pokazatelji investiranja, ukupna rentabilnost dionice ( Model 1) i prinos dionice ( Model 2 ). Pokazateljima investiranja mjeri se uspješnost ulaganja u dionice poduzeća. Ukupna rentabilnost dionice se ubraja u najvažnije pokazatelje investiranja a dobije se kao omjer dobiti po dionici (engl.earnings per share - EPS) i tržišne cijene po dionici ( engl. price per share - PPS), (Žager et.al,2018). Ukupna rentabilnost dionice izračunata je za svaku godinu za sve emitente u uzorku. Prinos dionice izražen kao relativna promjena cijena dionica je ključan indikator za potencijalne investitore $u$ analizi isplativosti ulaganja u određene dionice (Jakšić, 2007) te je također izračunat za svaku godinu za sve emitente u uzorku.

U modelu je ukupna rentabilnost dionice određena kao prosječna ukupna rentabilnost dionice emitenata u 6 godina, prinos dionice određen je kao prosječan godišnji prinos u 6 godina. Nezavisna varijabla u obadva modela je razina objava informacija o poslovanju prikazana kao dummy varijabla rangirana od 1-6, gdje emitenti koji su objavili sve zakonom zahtijevane informacije o poslovanju u 6 
godina imaju rang 6 , dok emitenti koji su sve zakonom zahtijevane informacije objavili u jednoj godini od mogućih 6 , imaju rang 1 . Veći iznos dummy varijable znači veću razinu objava svih zakonom zahtijevanih informacija o poslovanju i sukladno postavljenom istraživačkom pitanju trebao bi pozitivno utjecati na ukupnu rentabilnost i prinos dionice. Zbog potrebe uključivanja kontrolne varijable u model, u izboru više potencijalnih varijabli izabrana je varijabla rentabilnost vlastitog kapitala glavnice (engl.return to equity-ROE) izražena kao omjer neto dobiti i kapitala i rezervi ( Žager et al, 2017.). Vrijednost ROE je preuzeta sa internet stanice www.sase.ba i javno dostupnih podataka o pokazateljima emitenata svrstanih u Segment 1 SASE. Kod emitenata kod kojih nije bio dostupan podatak, ROE je izračunat prema navedenom omjeru. Ukupan uzorak u oba modela čini 31 emitent. Jedan emitent je isključen u oba modela zbog visoke vrijednosti, izdvojenica (engl. outliers). Zbog slabo likvidnog tržišta kapitala u Federaciji BiH cijene dionice imaju vrlo male i rijetke promjene što otežava pronalaženje varijabli uzročnika tih promjena koje bi imale visoku korelaciju sa prinosom dionice.

Tablica 3. Deskriptivna statistika modela

\begin{tabular}{|c|c|c|c|c|c|c|}
\hline & \multicolumn{3}{|c|}{ Model 1 } & \multicolumn{3}{c|}{ Model 2 } \\
\hline & $\begin{array}{c}\text { Ukupna } \\
\text { rentabil- } \\
\text { nost dio- } \\
\text { nice (E/P) }\end{array}$ & $\begin{array}{c}\text { Razina } \\
\text { objava }\end{array}$ & ROE & $\begin{array}{c}\text { Prinos dio- } \\
\text { nice }\end{array}$ & $\begin{array}{c}\text { Razina } \\
\text { objava }\end{array}$ & ROE \\
\hline $\begin{array}{c}\text { Aritmetička } \\
\text { sredina }\end{array}$ & $9,35 \%$ & 4,19 & $5,53 \%$ & $4,96 \%$ & 4,19 & $6,08 \%$ \\
\hline Medijan & $6,59 \%$ & 5 & $1,90 \%$ & $2,06 \%$ & 5 & $2,44 \%$ \\
\hline Mod & $0,00 \%$ & 6 & $0,00 \%$ & $\mathrm{n} / \mathrm{a}$ & 6 & $0,00 \%$ \\
\hline $\begin{array}{c}\text { Standardna } \\
\text { devijacija }\end{array}$ & $10,18 \%$ & 1,99 & $8,41 \%$ & $7,86 \%$ & 1,99 & $8,67 \%$ \\
\hline Minimum & $0,00 \%$ & 0 & $0,00 \%$ & $-2,16 \%$ & 0 & $0,00 \%$ \\
\hline $\begin{array}{c}\text { Maksimum } \\
45,16 \%\end{array}$ & 6 & $36,20 \%$ & $28,67 \%$ & 6 & $36,20 \%$ \\
\hline $\begin{array}{c}\text { Asimetrija } \\
\text { distribucije }\end{array}$ & 1,83 & $-0,75$ & 2,63 & 2,07 & $-0,75$ & 2,31 \\
\hline $\begin{array}{c}\text { Izduženost } \\
\text { distribucije }\end{array}$ & 4,00 & $-0,91$ & 7,25 & 3,93 & $-0,91$ & 5,53 \\
\hline $\begin{array}{c}\text { Broj poda- } \\
\text { taka }\end{array}$ & 31 & 31 & 31 & 31 & 31 & 31 \\
\hline
\end{tabular}

Izvor: Obrada autora 
Tablica 4. Modeli višestruke linearne regresije

\begin{tabular}{|c|c|c|c|c|c|}
\hline & $\begin{array}{c}\text { Varija- } \\
\text { bla: Razi- } \\
\text { na objava }\end{array}$ & $\begin{array}{c}\text { Varijabla: } \\
\text { ROE- Povrat } \\
\text { na kapital }\end{array}$ & $\begin{array}{c}\text { F-veli- } \\
\text { čina }\end{array}$ & F-test & Broj podataka \\
$\begin{array}{c}\text { Ukupna } \\
\text { rentabilnost } \\
\text { dionice (Model } \\
1)\end{array}$ & 0,0014 & 0,3383 & 1,2524 & 0,3013 & 31 \\
$\begin{array}{c}(0,0094) \\
\text { Prinos dioni- } \\
\text { ce (Model 2) }\end{array}$ & $-0,0023$ & $0,3328 * *$ & 2,1187 & 0,1390 & 31 \\
& $(-0,007)$ & $(0,1617)$ & & \\
\hline
\end{tabular}

* Razina signifikantnosti od $10 \%$ prikazana je kao *, razina signifikantnosti od $5 \%$ prikazana je kao **, Razina signifikantnosti od 1\% prikazana je kao ***. U zagradama su standardne devijacije parametara.

Izvor: Obrada autora

U modelima nije bilo moguće odbaciti pretpostavku o nepostojanju utjecaja razine objava informacija o poslovanju na ukupnu rentabilnost i prinos dionica. Oba parametra nisu značajna pri razini signifikantnosti od $10 \%$ te se odbacuje pretpostavka istraživanja da razina objava informacija o poslovanju djeluje pozitivno na ukupnu rentabilnost i prinos dionica emitenata na tržištu kapitala u Federaciji $\mathrm{BiH}$. Varijabla neto rentabilnost vlastitog kapitala, ROE je značajna na razini signifikantnosti od 5\% u modelu 2, što potvrđuje opravdanost ROE kao kontrolne varijable.

U svrhu utvrđivanja valjanosti procjena i testova modela izvršena je dijagnostika modela kao provjera postojanja narušenih pretpostavki. Oba modela zadovoljavaju postavljene pretpostavke, uz potencijalno narušavanje pretpostavki primjetno kod kriterija multikolinearnosti koji je testiran faktorom inflacije varijance (VIF). Visok indikator VIF dovodi do velikog povećanja varijance procijenjenih parametara i narušava pretpostavke modela. 
Tablica 5. Indikator multikolinearnosti VIF

\begin{tabular}{|c|c|c|}
\hline & Model 1 & Model 2 \\
\hline Razina objava & 5,814 & 5,719 \\
\hline $\begin{array}{c}\text { Neto rentabilnost vlastitog kapi- } \\
\text { tala-ROE }\end{array}$ & 1,504 & 1,544 \\
\hline
\end{tabular}

Izvor: Obrada autora

VIF indikator za oba modela pokazuje više vrijednosti kod varijable razina objava $(5,814$ i 5,719$)$ te niže vrijednosti kod varijable neto rentabilnost vlastitog kapitala - ROE (1,504 i 1,544). Prema Wooldridge (2012.) određivanje točne granice koja razdvaja problematičan od prihvatljivog VIF-a je proizvoljno, a moguća granica je VIF $>10$. Multikolinearnost podrazumijeva visoku korelaciju između nezavisnih varijabli koja bi narušila procjene i reprezentativnost modela. Potencijalni razlog niske razine mulitkolinearnosti je što rezultati modela ne mogu potvrditi utjecaj razine objava na zavisne varijable što sugerira nisku korelaciju između razine objava i kontrolne varijable. Ipak, zbog učestalog problema mulikolinearnosti u modelima višestruke regresije i u svrhu konačne potvrde prihvatljivosti oba modela koristi se tablica koeficijenata korelacije između varijabli.

Tablica 6. Koeficijenti korelacije između varijabli modela 1

\begin{tabular}{|c|c|c|c|}
\hline & \multicolumn{3}{|c|}{ Model 1 } \\
\hline & $\begin{array}{c}\text { Razina } \\
\text { objava }\end{array}$ & $\begin{array}{c}\text { Ukupna } \\
\text { rentabilno } \\
\text { st dionice }\end{array}$ & ROE \\
\hline $\begin{array}{c}\text { Razina } \\
\text { objava }\end{array}$ & 1 & 1 & \\
\hline $\begin{array}{c}\text { Ukupna } \\
\text { rentabilno } \\
\text { st dionice }\end{array}$ & $8,37 \%$ & $28,51 \%$ & 1 \\
\hline ROE & $19,77 \%$ & & \\
\hline
\end{tabular}

Izvor: Obrada autora
Tablica 7. Koeficijenti korelacije između varijabli modela 2

\begin{tabular}{|c|c|c|c|}
\hline & \multicolumn{3}{|c|}{ Model 2 } \\
\hline & $\begin{array}{c}\text { Razina } \\
\text { objava }\end{array}$ & $\begin{array}{c}\text { Prinos } \\
\text { dionice }\end{array}$ & ROE \\
\hline $\begin{array}{c}\text { Razina } \\
\text { objava }\end{array}$ & 1 & 1 & \\
\hline $\begin{array}{c}\text { Prinos } \\
\text { dionice }\end{array}$ & $0,36 \%$ & 1 & \\
\hline ROE & $15,21 \%$ & $35,77 \%$ & 1 \\
\hline
\end{tabular}

Izvor : Obrada autora

Obzirom da koeficijenti korelacije pokazuju vrlu nisku korelaciju $(19,77 \%$ i 15,21\%) između nezavisnih varijabli obadva modela, može se potvrditi nepostojanje dovoljno visoke multikolinearnosti kao narušene pretpostavke modela, stoga se potvrđuje zaključak o nepostojanju utjecaja razine objava informacija o poslovanju na ukupnu rentabilnost dionica i prinos dionica emitenata svrstanih $u$ Segment 1 Sarajevske burze. Vrlo niski koeficijenti korelacije između tih varijabli dodatno potvrđuju njihovu usku vezu. 


\section{ZAKLJUČAK}

Provedenim istraživanjem pokazalo se da razina objava informacija o poslovanju emitenata na tržištu kapitala u Federaciji BiH nije na zadovoljavajućoj razini. Emitenti ispunjavaju djelomično zakonski propisane obaveze za objavama, odnosno objavljuju samo glavni set financijskih izvještaja dok izvještaj vanjskog revizora koji je mehanizam kontrole financijskih izvještaja nije objavljen kod velikog dijela emitenata $(M=10)$. Emitenti također ne daju dodatne informacije uz prezentirane podatke koje bi bile od koristi za bolje razumijevanje podataka prezentiranih u financijskim izvještajima iako obrazac na kojem se objavljuju podaci zahtijevaju takve objave. Objave o događajima koje bitno utječu na poslovanje se najčešće odnose na objavu o sazivanju skupštine društva, dnevnog reda i eventualno odluka donesenih na istoj. Nadalje, regresijskom analizom se nije utvrdio utjecaj razine objava informacija o poslovanju na ukupnu rentabilnost dionica i prinos dionica emitenata na tržištu kapitala u Federaciji BiH svrstanih u Segment 1 Sarajevske burze, za što razlozi mogu biti i u nedovoljnoj razini objava informacija o poslovanju te nedovoljno razvijenom tržištu kapitala u Federaciji BiH. Primjetno je tijekom provedbe istraživanja da broj emitenata svrstanih u Segment 1 SASE tijekom promatranog razdoblja opada, u 2013 godini je brojio 30 emitenata dok je u trenutku provedbe istraživanja (svibanj, 2020. godine) brojio tek 20 emitenata što može biti i posljedica sankcioniranja Sarajevske burze onih emitenata koji ne objavljuju podatke i za posljedicu imaju presegmentiranje u niži segment Slobodnog tržišta. Svakako bi u idućim istraživanjima bilo zanimljivo vidjeti koji su pravi razlozi smanjenja broja emitenata u Segmentu 1 SASE. Također, u budućim istraživanjima bi bilo zanimljivo istražiti koji faktori utječu na razinu objava informacija o poslovanju pored zakonskih zahtjeva, da li je to vrsta vlasništva, vrsta djelatnosti, struktura upravnih odbora emitenata sa proširenjem istraživanja na emitente tržišta kapitala u Republici Srpskoj.

Navedeni zaključci upućuju da u Federaciji Bosne i Hercegovine ima još jako puno prostora ali i potrebe za unapređenje objava informacija o poslovanju u čemu će zasigurno pomoći i usklađivanje aktualne zakonske regulative prije svega Zakona o računovodstvu i reviziji F BiH koji nije mijenjan od 2009. godine sa regulatornim okvirom Europske unije za korporativno izvještavanje. 


\section{LITERATURA}

1. Botosan, C.A. (1997.). Disclosure level and the cost of equity capital. The Accounting Review, 72(3),p. 323-349.

2. Brkanić, V. (2007.).Računovodstvo poduzetnika. Međunarodni standardi financijskog izvještavanja, RRiF, Zagreb, str.136.

3. Gulin, D., Grbavac, J., Hladika, M. (2016.). Kvaliteta korporativnog izvještavanja kao pretpostavka transparentnosti poslovnih subjekata. Zbornik radova Ekonomskog fakulteta Sveučilišta u Mostaru, (Posebno izdanje 2016), str. 154-180.

4. Hussainey, K., Walker, M. (2009.). The Effects of Voluntary Disclosure and Dividend Propensity on Prices Leading Earnings. Accounting and Business Research, 39 (1).

5. Jakšić, S. (2007). Primjena Markowitzeve teorije na tržište dionica Zagrebačke burze. Zbornik Ekonomskog fakulteta u Zagrebu, 5 (1), 331-344. Preuzeto s https://hrcak.srce.hr/26139Jakšić, S. (2007.). Primjena Markowitzeve teorije na tržište dionica Zagrebačke burze. Zbornik Ekonomskog fakulteta u Zagrebu, 5 (1), 331-344. Preuzeto s https://hrcak.srce.hr/26139.

6. Madhani, P. M. (2007.). Role of voluntary disclosure and transparency in financial reporting. The Accounting World, vol. 7, no. 6, p. 63-66.

7. Međunarodni računovodstveni standardi i Međunarodni standardi financijskog izvještavanja preuzeti sa web stranice Saveza računovođa i revizora F $\mathrm{BiH}$.

8. Mishkin, F.S., Eakins, S.G. (2005.). Financijska tržišta i institucije. Mate, Zagreb, 2005.

9. Mwangi, M., Mwiti, J. K (2015.). The effect of voluntary disclosure on stock market returns of companies listed at the Nairobi securities exchange. International journal of humanities and social science, 1(6); pp. 99-105.

10. Pravilnik o objavljivanju informacija i izvještavanju na tržištu vrijednosnih papira (Službene novine F BiH, br. 35/13, 65/19).

11. Sahore, N. S., Verma, A. (2017.). Corporate Disclosures and Financial Performance of Selected Indian Manufacturing and Non- Manufacturing Companies. Accounting and Finance Research, 6(1), 119. doi:10.5430/afr. v6n1p119 .

12. Žager, K., Sačer M.I., Mališ S.S., Ježovita A., Žager L.(2017.). Analiza financijskih izvještaja, načela-postupci-slučajevi, Zagreb, Delfin-Hrvatska zajednica računovođa i revizora.

13. Zakon o računovodstvu i reviziji BiH (Sl. glasnik BiH, br.42/04).

14. Zakon o računovodstvu i reviziji u Federaciji BiH (Sl.novine F BiHbr.83/09). 
15. Zakon o tržištu vrijednosnih papira F BiH (Sl.novine F BiH br.85/08, 109/12).

16. Zareian, M. (2012.). Voluntary Disclosure of Information and Stock Returns. International Journal of Engineering Research and Applications, 2(3), 27,62-66.

17. Wooldridge J.M. (2012.). Introductory econometrics: a modern approach. 5th edition. South-Western, Cengage Learning. 


\title{
Suzi Mikulić
}

Croatian Telecom JSC, Kneza Branimira bb, Mostar

suzi.mikulic@gmail.com

\section{THE EFFECTS OF THE LEVEL OF DISCLOSURES ON EARNINGS /PRICE RATIO AND STOCK YIELD ON THE CAPITAL MARKET IN THE FEDERATION OF BOSNIA AND HERZEGOVINA}

Received: September 24, 2020

Accepted: October 16, 2020

https://doi.org/10.46458/27121097.2020.26.146

Review

\begin{abstract}
Information are one of the basic resources for business, and without them, it is not possible to make quality and timely business decisions. With the development of financial markets and the growing number of information stakeholders, the requirements for disclosures are continuously increasing. The way on which issuers communicate with potential investors and all other stakeholders are publicly available disclosures, whether they are on mandatory or voluntary base. This paper examines the disclosures on the capital market in the Federation of $\mathrm{BiH}$, classified in the Segment 1 (ST1) of the Sarajevo Stock Exchange (SASE), in the period from 2013 to 2018, and whether the level of disclosures affects the earnings/ price ratio and price yield of the issuers. The research established that issuers classified in the ST1 partially meet the legally prescribed obligations in publishing information. They publish only the main set of financial statements, while the external auditor's report, which is the control mechanism of financial statements, was not published by a significant number of issuers. The scope of publishing voluntary information is not on a satisfactory level due to the still relatively undeveloped capital market in the F BiH compared to more developed countries and the fact that Bosnia and Herzegovina is not a member of the European Union and has not yet harmonized legal requirements with the EU regulatory framework for corporate reporting. The performed regression analysis did not confirm the impact of the level of disclosures on the earnings / price ratio and price yield of the issuers.
\end{abstract}

Keywords: disclosures, financial statements, earnings / price ratio, share yield

JEL: G30, M40, M41 